\title{
TUMOURS OF THE LUNG AND THE CARCINOID SYNDROME
}

\author{
BY \\ E. D. WILlIAMS AND J. G. AZZOPARDI \\ From the Department of Pathology, Postgraduate Medical School, Hammersmith Hospital, London
}

(RECEIVED FOR PUBLICATION OCTOBER 24, 1959)

The majority of bronchial adenomas show a histological structure usually described as carcinoid in type. Until recently the term "carcinoid" used in this way was meant to be descriptive only, on the understanding that this tumour bore no relationship to the better-known carcinoids of the alimentary tract. This sharp distinction has been challenged histologically by Feyrter (1959a) and on functional grounds by Stanford, Davis, Gunter, and Hobart (1958) and by other workers who have described cases with metastasizing bronchial adenomas and the clinical and biochemical features of the carcinoid syndrome. The characteristics of the carcinoid syndrome in association with malignant argentaffinomas of the small bowel have been well described by Thorson, Bïorck, Björkman, and Waldenström (1954) and many other writers. A case of bronchial adenoma previously published by Kincaid-Smith and Brossy (1956) has since shown features similar to those of the American workers. The new data on this case are presented here, together with some observations that cast light on the possible relationship between the carcinoid type of bronchial adenomas and carcinoids of the bowel. In addition, a case of oat-cell carcinoma of the bronchus with an associated "carcinoid" syndrome is reported.

The small group of bronchial and tracheal tumours of the adenoid cystic type ("cylindromas") are quite distinct from the carcinoid type, and are not discussed further. The clinicopathological differences between the two types have been summarized by Feyrter (1959a and b).

\section{CASE Reports}

CASE 1.*-Mrs. W.A., aged 58, was first seen in Mr. Cleland's clinic in February, 1948, complaining of a cough and blood-streaked sputum. There was radiological evidence of collapse of the middle lobe of the right lung. A right middle and lower

* An account of this case up to March, 1955, has been published by Kincaid-Smith and Brossy (1956). lobectomy was performed after biopsy. A bronchial $\vec{\omega}$ adenoma, $11 \mathrm{~mm}$. in diameter and $35 \mathrm{~mm}$. long, occupied the medial branch of the middle lobe $\frac{}{3}$ bronchus and extended into the lung parenchyma. Microscopieally, it was a carcinoid type of bronchial $\bar{z}$ adenoma (Fig. 1) with invasion of lymphatics. The patient was well until April, 1954, when she developed $\stackrel{5}{工}$ intermittent watery diarrhoea with no blood or mucus $\vec{\ominus}$ in the stools; this was accompanied by flatulence, $\mathscr{O}$ colic, and abdominal rumblings. About this time she also complained of episodes of facial flushing. In September, 1954, a rounded tumour was felt in

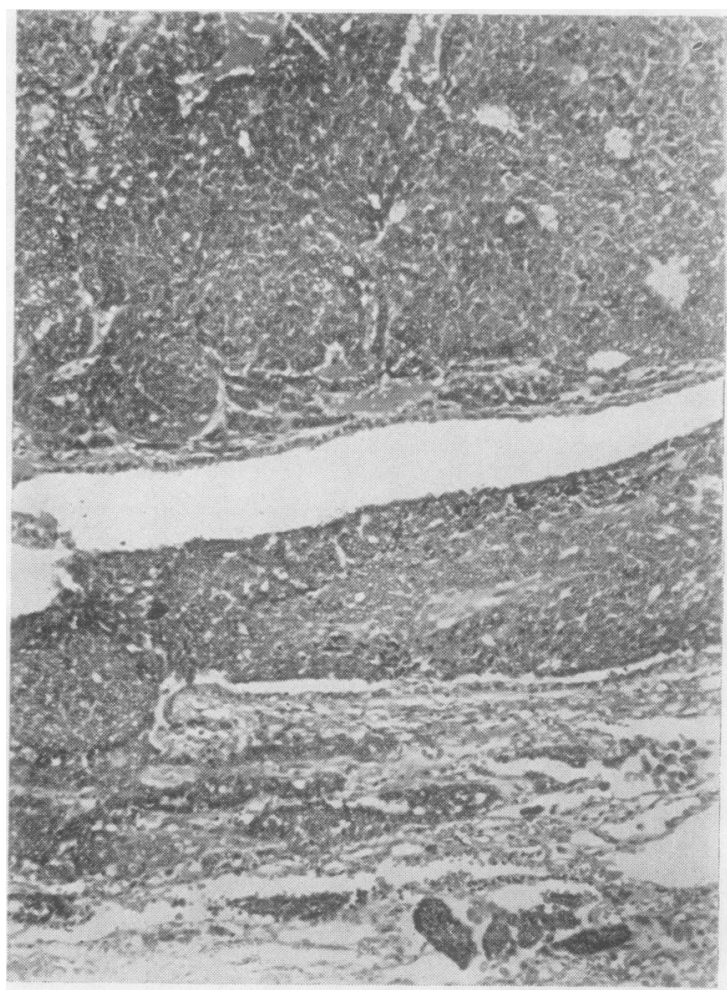

FIg. 1.-Bronchial adenoma from Case 1 showing intra- and extraluminal growth (haematoxylin and eosin $\times 95$ ). 
the left hypochondrium. A barium meal and followthrough and barium enema revealed no evidence of tumour in the alimentary tract. Sigmoidoscopy was normal. At laparotomy in October, 1954, a cystic tumour, $10 \mathrm{~cm}$. in diameter, was removed from the edge of the left lobe of the liver. The histology was identical with that of the bronchial neoplasm previously removed. After this operation episodic diarrhoea and flushing did not recur for over two years. In December, 1956, the patient herself suspected recurrence of the tumour because of the reappearance of bouts of facial flushing and diarrhoea. In May, 1957, at a routine follow-up examination a mass was palpated in the right hypochondrium and epigastrium. At laparotomy in June, 1957, numerous metastatic nodules were found in the liver and biopsies were taken. These showed histological appearances identical with those of the two previously removed neoplastic masses. The 24-hour urinary excretion of 5-hydroxy indole acetic acid (5-H.I.A.A.) was measured immediately before the last operation and found to be $74 \mathrm{mg}$. A post-operative estimation was $100 \mathrm{mg}$. $/ 24$ hours; both results are well up to the level seen with functioning carcinoid tumours. The patient continued to have bouts of diarrhoea and flushings. Her course was progressively downhill and she died in a nursing-home in December, 1957. No post-mortem examination was carried out.

CASE 2.-Mr. J. B., aged 72 at the time of his final illness, was admitted to Hammersmith Hospital under the care of Professor Sheila Sherlock in September, 1957. He complained of loss of weight and anorexia for seven months, and diarrhoea, accompanied by pain in the right iliac fossa, for two months. The diarrhoea began after a short period of constipation ; there were up to 20 watery brown stools daily. The abdominal pain and discomfort were relieved by defaecation. There was no mucus in the stools and no altered blood, but there was a small amount of bright red blood attributable to an anal fissure.

On examination, he was a thin old man showing palmar erythema. There was no peripheral oedema. The abdomen was distended and there was a small para-umbilical hernia. The liver edge was palpable five fingerbreadths beneath the costal margin. It was firm, smooth and not tender. The spleen was not palpable. There was no evidence of ascites. Pulse was $70 /$ minute, regular, and the blood pressure was $120 / 60 \mathrm{~mm}$. Hg. The cardiovascular, respiratory, and other systems were normal. The haemoglobin was 15.0 g. $/ 100 \mathrm{ml}$., the W.B.C. $10,000 / \mathrm{c} . \mathrm{mm}$. with $82 \%$ neutrophils, and the E.S.R. was $20 \mathrm{~mm}$. in one hour (Wintrobe). Total protein was $6.4 \mathrm{~g} . / 100 \mathrm{ml}$. (globulin $3.3 \mathrm{~g} . / 100 \mathrm{ml}$, $\gamma$-globulin $1: 1 \mathrm{~g} . / 100 \mathrm{ml}$.). Thymol turbidity and zinc sulphate turbidity were normal, and the serum alkaline phosphatase was $\mathbf{3 1 . 5}$ King-Armstrong units $/ 100 \mathrm{ml}$. The blood urea was $26 \mathrm{mg} . / 100 \mathrm{ml}$. Liver biopsy contained metastatic carcinoma with the histological appearances of oatcell carcinoma of the bronchus. A chest radiograph at this time showed no definite evidence of bronchial tumour.
In view of the persistence of watery diarrhoea the 5-H.I.A.A. excretion was measured. The 24-hour urinary output was found to be $64.1 \mathrm{mg}$. This level was regarded as diagnostic of carcinoid tumour. A repeat estimation 17 days later was $55 \mathrm{mg}$./24 hours ; the true value was probably higher in view of several days' delay between collection of the specimen and its analysis.

Three weeks after admission the patient had an episode of facial flushing with tachycardia and an increase in respiratory rate, but no wheezing. $\mathrm{He}$ continued to suffer from diarrhoea, colicky abdominal pain, and periodic flushings not associated with cyanosis, eventually showing almost permanent facial flushing. His condition slowly deteriorated and he died five weeks after admission to hospital.

A necropsy was carried out seven hours after death. The main findings follow here.

Respiratory System.-Both pleural cavities were obliterated by fibrous adhesions. The apical bronchus of the lower lobe of the right lung was surrounded by a small primary carcinoma. The tumour was white and of firm consistency, and was $11 \mathrm{~mm}$. in diameter. Both lower lobes showed a purulent bronchopneumonia. There were no other tumour deposits in the lungs.

Cardiovascular System.- The heart (335 g.) showed slight atheroma of the coronary arteries. All chambers and valves were normal.

Alimentary Tract.-There were three small superficial ulcers in the pyloric antrum. A careful search of both small and large intestines, including the appendix, revealed no tumour. The liver was greatly enlarged, weighing 4,900 g. It was riddled with metastatic deposits of white tumour. The biliary passages were normal. The pancreas contained numerous deposits of secondary tumour.

Genito-urinary System.-The kidneys each weighed $135 \mathrm{~g}$. and showed a normal pattern. The prostate showed a benign nodular hyperplasia. The testes were normal.

Endocrines.-The thyroid was normal and the adrenals contained many small white tumour deposits in the medulla.

Reticulo-endothelial System. - Lymph nodes, enlarged and replaced by tumour, were present in the right hilar and paratracheal groups and in the porta hepatis. The spleen $(235 \mathrm{~g}$.) was normal on section. There were numerous small metastatic deposits in the vertebral bone marrow.

The central nervous system was not examined.

Microscopical examination of the primary lung tumour and of the secondary deposits in the liver, pancreas, adrenals, bones, and lymph nodes showed the typical pattern of an oat-cell carcinoma (Fig. 2). Sections of the gastric ulcers showed acute peptic erosion.

\section{COMment AND Further Investigations}

There is an obvious close clinical and biochemical similarity between the syndromes 


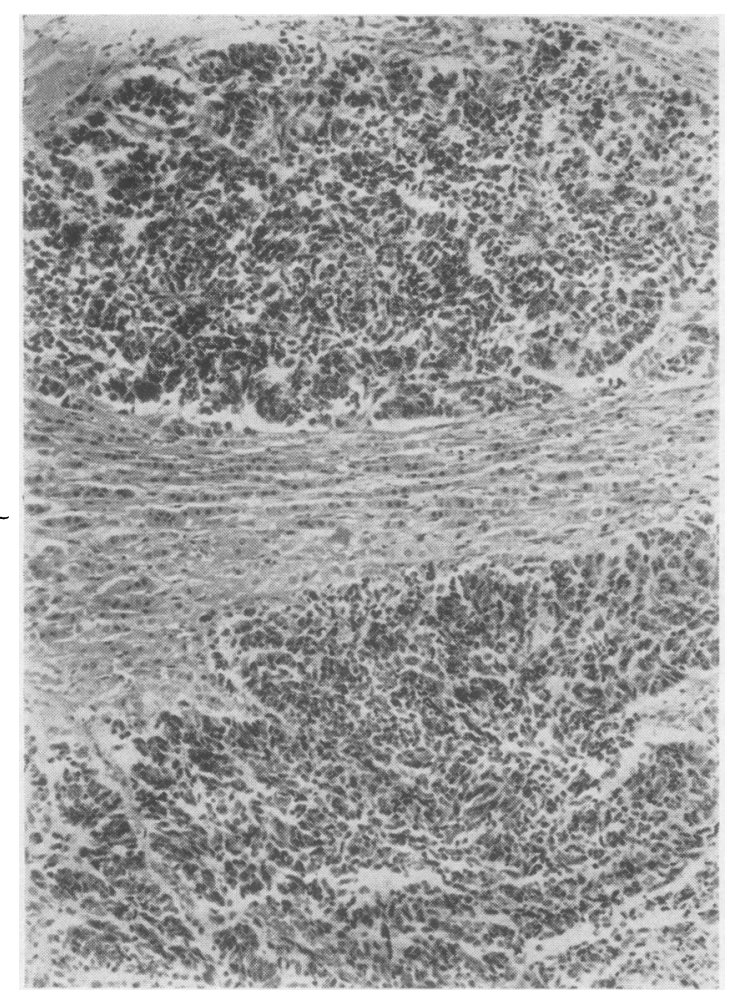

FIG. 2.-Oat-cell carcinoma. Secondary deposit in adrenal from Case 2 (haematoxylin and eosin $\times 95$ ).

produced by some carcinoid tumours of the bowel, the cases described here, and the small group of metastasizing bronchial adenomas previously reported.

In only two of the six well-documented cases with a carcinoid syndrome and a metastasizing bronchial adenoma was a post-mortem examination carried out. It is therefore theoretically possible that in the other examples there was a separate primary carcinoid of the intestine responsible for the metastases. We have not been able to trace any cases in which there has been both a primary carcinoid of the intestine and a bronchial adenoma, although pulmonary metastasis from an intestinal carcinoid has been reported.

In Case 1 the bronchial adenoma was obviously a primary tumour because of the typical macroscopic appearance. The secondary deposits were histologically extremely similar to the bronchial tumour, and the special staining reactions of both primary and secondary tumours were the same, and were similar to those of the other bronchial adenomas. No primary abdominal tumour was found on $x$-ray examination or on surgical $\stackrel{\overrightarrow{\bar{S}}}{\rightarrow}$ exploration of the abdomen. For these reasons we believe that the known primary tumour in the bronchus was the source of the secondary deposits which gave rise to the syndrome. It is of interest that in one of the other reported cases of metastasizing bronchial adenoma, and in the present case, a secondary deposit formed a cystic mass in the extreme edge of the left lobe of the liver. In three of the other cases some of the secondary deposits in the liver were noted to be large and centrally cystic.

The two cases reported here were investigated histochemically to elucidate their relationship to the carcinoid tumours of the bowel, and these investigations were also carried out on a further eight cases of bronchial adenoma removed surgically at Hammersmith Hospital. All nine of the bronchial adenomas were of the "carcinoid" type.

The investigations carried out included the Masson-Fontana and diazonium reactions. Cytoplasmic granules which give positive results with

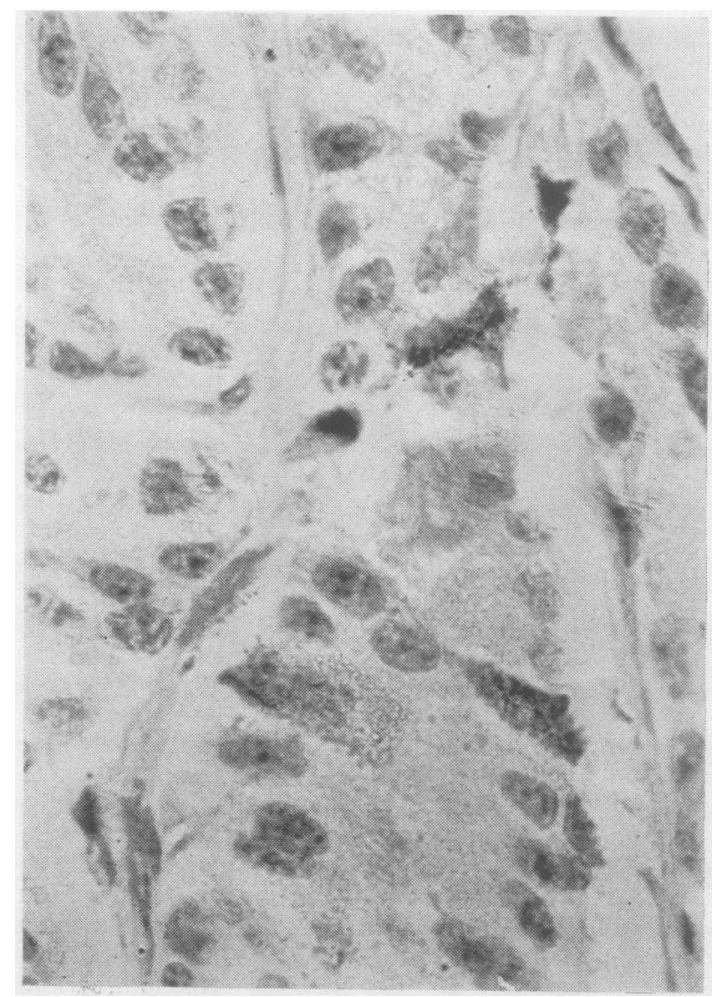

FIG. 3.-Argentafin cells in a bronchial adenoma (Masson's silver $\times 1,400)$. 
these methods are characteristic of Kultschitzsky cells and are usually seen in carcinoids of the small intestine when formalin fixation has been employed. The Bodian silver technique is also positive in intestinal carcinoids, as is Schmorl's reaction, which is a test for the presence of reducing substances. Both Kultschitzsky cells and the intestinal carcinoids show a yellow autofluorescence in ultra-violet light after formalin fixation; this is thought to be due to the presence of 5-hydroxytryptamine (5-H.T.). Both fresh and formalin-fixed intestinal carcinoids are usually yellow on macroscopic examination.

In four of the nine bronchial adenomas investigated a few cells containing the silver-reducing (argentaffin) granules as shown by the MassonFontana technique were found (Fig. 3) and in three of these tumours there were cells containing positive granules with the more specific diazonium reaction. With the Bodian silver method (Hamperl, 1952), impregnated cells were found in varying numbers in seven out of the nine bronchial adenomas. This method demonstrates silver impregnable (argyrophil) cells and is generally considered less specific than the silver reducing method demonstrating argentaffin properties. The tumour from Case 1 was argyrophil (Fig. 4), and a few cells with argentaffin and diazo-positive granules were found in both primary and metastatic tumour tissue. Seven of the tumours contained cells that were weakly positive with the Schmorl's reaction. In reviewing the nine bronchial adenomas it was noted that in two cases the blocks of formalin-fixed tissue showed a fairly deep yellow colour, and in three others a pale yellow colour. The remaining four cases were grey-white. The two tumours with the brightest yellow colour were also those that gave the strongest argyrophilic reaction. When examined in ultra-violet light, all but one of the tumours gave a yellow fluorescence of varying intensity. The Bodian technique was carried out on several sections after they had been examined for fluorescence and photographed under ultra-violet light. It was found that the individual cells which were highly fluorescent under ultra-violet light were also strongly argyrophilic. It was also noted that the fluorescence was brighter in the nuclei than in the cytoplasm. It was shown that the strongly fluorescent cells also gave the deepest staining with the Schmorl's reaction by the same method.

These investigations were also performed on sections of tumour from a case of the functioning carcinoid syndrome with a primary carcinoid in the ileum. No argentaffin granules were found in the

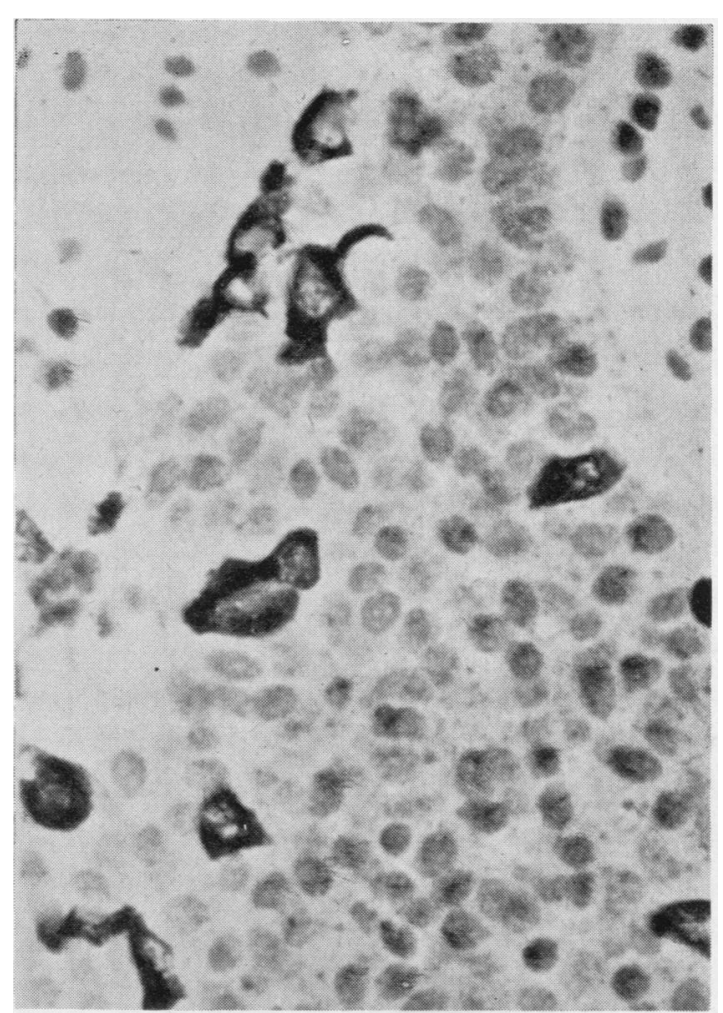

Fig. 4.-Argyrophil cells in the bronchial adenoma from Case 1 (Bodian's protargol method $\times 1,370$ ).

post-mortem material from this case, but this is not surprising since the argentaffin reaction is known to disappear within a few hours of death. It is, however, pertinent to our findings in the bronchial adenomas that the ileal carcinoid retained both argyrophilia and its yellow fluorescence in the ultra-violet light. The fluorescence in this case was also noted to be stronger in the nuclei than in the cytoplasm.

The oat-cell carcinoma (Case 2) showed a yellow fluorescence in some areas ; Masson, Diazo, and Bodian techniques all gave a negative result on both liver biopsy and post-mortem material, but a weak positive result was obtained with the Schmorl's reaction. The fluorescence was fairly weak and very variable, and some secondary deposits showed no fluorescence at all. In the areas where fluorescence occurred it was once again mainly nuclear. There were no histological differences between the fluorescent and nonfluorescent areas. A sample of tumour tissue taken nine hours after death was kindly analysed by Dr. C. E. Dalgliesh and a 5-H.T. content of $20 \mu \mathrm{g}$. $/ \mathrm{g}$. wet weight found. This value is very 
much less than the levels reported in most functioning intestinal carcinoids (Lembeck, 1953), but it is much higher than figures given for normal mammalian tissues. Tumour tissue from one case of the functioning carcinoid syndrome with a primary in the stomach gave a value of only 0.33 $\mu$ g. 5-H.T. (Lennard-Jones and Snow, 1956).

Surgically removed squamous, oat-cell, and adenocarcinomas of the bronchus were used as control material. In no case was there a yellow fluorescence in ultra-violet light, and no argentaffin or argyrophilic cells were seen.

\section{Discussion}

In the past, the differences rather than the similarities between the carcinoid type of bronchial adenoma and the carcinoid tumours of the alimentary tract have been stressed. The main histological distinction which has been relied upon has been the absence of argentaffin granules in the bronchial adenomas. There has been one oftenquoted exception: Holley (1946) found one case with argentaffin granules in a series of 30 bronchial adenomas. A recent article by Feyrter (1959a) states that seven out of 19 tumours contained argentaffin cells, although diazo-positive cells were found in only two. Our finding, that of nine bronchial adenomas four contained argentaffin cells and three contained cells that were diazo-positive, stresses the fact that these reactions are not a major point of difference between carcinoids of the gut and bronchial adenomas. However, there is a striking difference in degree between the two groups: in the bronchial adenomas the cells containing positive granules were few and were found with difficulty: in the intestinal carcinoids, cells containing argentaffin and diazopositive granules are generally numerous. The granules in the intestinal carcinoids also tend to stain more heavily than those of the bronchial adenomas. The finding that a high proportion of bronchial adenomas contained argyrophil cells and gave positive results with Schmorl's stain is also a point of similarity between this tumour and carcinoids of the small intestine; argyrophilia has also been described in bronchial adenomas by Hamperl and Feyrter. In addition to these similarities with standard histological techniques, the yellow colour typical of intestinal carcinoids has been seen in many bronchial adenomas, and the yellow fluorescence in ultra-violet light which is seen in formalin-fixed Kultschitzsky cells and intestinal carcinoids is found to some degree in most of the bronchial tumours.

The clinical behaviour of these two groups of tumours is very similar; both are slow growing and locally invasive, often with long survival even in the presence of metastases. With the additional evidence that six well-documented cases of bronchial adenoma with a carcinoid syndrome have now been reported (see Table I), it must be accepted that the carcinoid type of bronchial adenoma and the carcinoids of the small intestine belong to the same group of tumours. We prefer to use the term " bronchial carcinoid" in place of the cumbersome " bronchial adenoma of carcinoid type." In this sense the term "carcinoid" would be used to describe a tumour of characteristic morphology and behaviour, with the occasional

TABLE I

CASES OF A CARCINOID SYNDROME ASSOCIATED WITH METASTASIZING BRONCHIAL ADENOMA

\begin{tabular}{|c|c|c|c|c|c|c|}
\hline Author & $\begin{array}{l}\text { Age and } \\
\text { Sex of } \\
\text { Patient }\end{array}$ & $\begin{array}{c}\text { Known Sites of } \\
\text { Metastasis }\end{array}$ & $\begin{array}{l}\text { Argentafin } \\
\text { Reaction of } \\
\text { Tumour }\end{array}$ & $\begin{array}{l}\text { S-H.I.A.A. } \\
\text { Content of } \\
\text { Urine }\end{array}$ & $\begin{array}{c}\text { Interval Between } \\
\text { Removal of Bronchial } \\
\text { Adenoma and Onset } \\
\text { of Syndrome }\end{array}$ & $\begin{array}{c}\text { Proof of Absence } \\
\text { of Primary } \\
\text { Carcinoid of Gut }\end{array}$ \\
\hline Stanford et al. (1958) & $42 \mathrm{~F}$ & $\begin{array}{l}\text { Single, large, partly } \\
\text { degenerate secondary } \\
\text { in liver edge }\end{array}$ & $\begin{array}{l}\text { Positive in } \\
\text { secondary }\end{array}$ & $\begin{array}{l}38 \text { and } 46 \mathrm{mg} \cdot / 24 \\
\mathrm{hr} \text {. }\end{array}$ & 6 years & $\begin{array}{l}\text { Radiology and } \\
\text { laparotomy }\end{array}$ \\
\hline Dockerty et al. (1958) & $54 \mathrm{~F}$ & $\begin{array}{l}\text { Single, very large, partly } \\
\text { liquefied hepatic secon- } \\
\text { dary }\end{array}$ & Not recorded & $\begin{array}{l}\text { Positive qualita- } \\
\text { tive test }\end{array}$ & 1 year 3 months & Laparotomy \\
\hline $\begin{array}{l}\text { Warner and Southren } \\
\text { (1958) }\end{array}$ & $\begin{array}{ll}48 & F \\
55 & F\end{array}$ & $\begin{array}{l}\text { Liver, spleen, lymph } \\
\text { nodes, and bones } \\
\text { Liver }\end{array}$ & $\begin{array}{l}\text { Negative } \\
\text { Not recorded }\end{array}$ & $\begin{array}{l}51 \text { and } 187 \\
\text { mg./24 hr. } \\
\text { Positive quali- } \\
\text { tative test }\end{array}$ & $\begin{array}{l}5 \text { years } 5 \text { months } \\
5 \text { years } 2 \text { months }\end{array}$ & $\begin{array}{l}\text { Necropsy } \\
\text { Radiology }\end{array}$ \\
\hline $\begin{array}{l}\text { Schneckloth et al. } \\
\text { (1959) }\end{array}$ & $.45 \mathrm{M}$ & $\begin{array}{l}\text { Single, very large necro- } \\
\text { tic secondary in right } \\
\text { lobe of liver }\end{array}$ & $\begin{array}{l}\text { Negative in } \\
\text { secondary }\end{array}$ & $77 \mathrm{mg} . / 24 \mathrm{hr}$. & 3 months & Necropsy \\
\hline Case 1 of this paper & $68 \mathrm{~F}$ & $\begin{array}{l}\text { Cystic secondary } 10 \mathrm{~cm} \text {. } \\
\text { in diameter in liver } \\
\text { edge. Many other } \\
\text { secondaries in liver later }\end{array}$ & $\begin{array}{l}\text { Positive in } \\
\text { primary and } \\
\text { secondary }\end{array}$ & $\begin{array}{l}74 \text { and } 100 \\
\mathrm{mg} . / 24 \mathrm{hr} \text {. }\end{array}$ & 6 years & $\begin{array}{l}\text { Radiology and } \\
\text { laparotomy }\end{array}$ \\
\hline Mattingly (1956) & $\begin{array}{l}\text { Not } \\
\text { recorded }\end{array}$ & $\begin{array}{l}\text { Liver, lymph nodes, } \\
\text { spleen, pancreas, } \\
\text { kidney, adrenal, } \\
\text { pituitary, and bones }\end{array}$ & Not recorded & Not recorded & $\begin{array}{l}\text { Tumour discovered } \\
\text { at necropsy, atypical } \\
\text { morphology for } \\
\text { bronchial adenoma }\end{array}$ & Necropsy \\
\hline
\end{tabular}


ability to give rise to the typical carcinoid syndrome. The rare histologically similar tumours of the colon and rectum would also belong to the same group; several of these tumours have been reported to contain argentaffin cells (Horn, 1949; Morson, 1956), and occasional carcinoid tumours in other sites also occur. In all the recorded cases of carcinoid tumours that we have been able to trace, the primary site has been in an organ derived embryologically from entoderm, or in a teratoma, with one exception in which there was a carcinoid of the parotid gland (Nicod, 1958).

The staining reactions of the various tumours have up to now been described purely empirically, without reference to the histochemical basis, but it is of interest to try to correlate these reactions with the function of the cell. The argentaffin reaction is positive only in formalin-fixed sections; it has been shown to be given also by 5-hydroxytryptamine after treatment with formalin in vitro (Barter and Pearse, 1953 ; Benditt and Wong, 1957). However, the first case described here contained only occasional argentaffin cells, and the second contained none, while in both there was a high excretion of 5-H.I.A.A., the breakdown product of 5-H.T. There have been a number of case reports of functioning carcinoid tumours without argentaffin cells (Thorson, 1958 ; Waldenström, Pernow, and Silwer, 1956) including one (Smith, Nyhus, Dalgliesh, Dutton, Lennox, and Macfarlane, 1957) in which the tumour was shown to contain high amounts of 5-H.T. The likely explanation here is that the granules of the Kultchitzsky cell and of some carcinoid tumours are aggregations of a storage material which retains the soluble 5-H.T. in the cytoplasm in a form in which, after formalin treatment, it is argentaffin. Evidence in favour of this is the observation that the granules of the enterochromaffin cell disappear on treatment with proteolytic enzymes (Jacobson, 1939). In the absence of this storage substance, any 5-H.T. contained in the cell is freely diffusible, and at death some may become bound to a constituent of the nucleus. As 5-H.T. (which is a strong reducing agent) gives a yellow fluorescence in ultra-violet light after formalin fixation, it seems probable that 5-H.T. itself or a closely related substance is responsible for the fluorescence observed in the bronchial adenomas. The weak positive results with Schmorl's test may also be due to this substance. These speculations are supported by the fact that frozen sections of several tissues dipped into a $10 \%$ solution of
5-H.T. for five minutes, and fixed in formalin, gave a weak positive Schmorl's, and also showed a yellow fluorescence in ultra-violet light. The nuclei were more fluorescent than the cytoplasm, as is the case in the bronchial carcinoid and the post-mortem material from the ileal carcinoid. In a recent case report of a metastasizing bronchial adenoma with the carcinoid syndrome (Schneckloth, McIsaac, and Page, 1959), the tumour was found to contain $100 \mu \mathrm{g}$. of 5-H.T./g. of wet tissue, and there were considerably greater amounts of a hydroxyindole thought to be an oxidation product of serotonin. The basis of the Bodian argyrophil reaction is unknown.

Since necropsy on the second case revealed no carcinoid, the oat-cell carcinoma must have been the source of the substance, presumably 5-H.T., causing the clinical syndrome described. The findings of a yellow fluorescence and a weakly positive Schmorl's test would support this. The tumour content of 5-H.T., while above normal, was a good deal lower than that of most reported functioning carcinoids. However, two factors might account for this discrepancy; first, the variation in secretion of 5-H.T. in various parts of the tumour, and secondly the probable absence of any storage mechanism for the substance. The first suggestion is supported by the variation in the autofluorescence, and the second by the absence of any cytoplasmic granules.

We have traced one relevant case of carcinoma of the bronchus with a possible carcinoid syndrome (Harrison, Montgomery, Robertson, Ramsey, and Welbourn, 1957). In this case the tumour was also an oat-cell carcinoma, and no carcinoid was found at necropsy. The carcinoid syndrome in one of the cases reported by Smith et al. (1957) was thought to have been due to an anaplastic carcinoma from an unknown primary site.

The production of the same syndrome by tumours as histogenetically distinct as the bronchial carcinoid and the oat-cell carcinoma is difficult to explain. However, oat-cell carcinomas have recently been shown to contain small ductlike spaces containing eosinophilic mucin similar to those seen in bronchial adenomas (Azzopardi, 1959). This does suggest that oat-cell tumours may undergo some structural differentiation, and the case reported here shows that the cells are also capable of a functional differentiation leading to the production of 5-H.T. or a similar substance. If enough cases of the association between this extremely interesting syndrome and tumours outside the carcinoid group are published, further speculation may be possible in the future. 


\section{SUMMARY}

Two cases of the carcinoid syndrome, one with a metastasizing bronchial adenoma and the other with an oat-cell carcinoma of the bronchus with widespread secondary deposits, are reported and similar cases reviewed.

Study of a group of bronchial adenomas shows the existence of definite affinities between these tumours and carcinoid tumours of the intestine, and we suggest that the "bronchial adenoma of carcinoid type" can justifiably be termed "bronchial carcinoid" on the basis of histology, histochemistry, and clinical behaviour.

We are indebted to Mr. W. P. Cleland, Mr. R. H. Franklin, and to Professor Sheila Sherlock for permission to study and publish details of their cases. We are also grateful to Professor C. V. Harrison, Dr. I. Doniach, and Dr. A. G. E. Pearse for much helpful criticism and advice, to Mr. J. Griffin and staff and Mrs. S. Hussey for histological assistance, and to Mr. W. Brackenbury for the photographs.

\section{REFERENCES}

Azzopardi, J. G. (1959). J. Path. Bact., 78, 513.

Barter, R., and Pearse, A. G. E. (1953). Nature (Lond.), 172, 810.

Benditt, E. P., and Wong, R. L. (1957). J. exp. Med., 105, 509.

Dockerty, M. B., McGoon, D. C., Fontana, R. S., and Scudamore, H. H. (1958). Med. Clin. N. Amer., 42, 975

Feyrter, F. (1959a). Virchows Arch. path. Anat., 332, 25.

(1959b). Ibid., 332, 44

Hamperl, H. (1952). Ibid., 321, 482

Harrison, M. T., Montgomery, D. A. D., Robertson, J. H., Ramsey, A. S., and Welbourn, R. B. (1957). Lancet, 1, 23.

Holley, S. W. (1946). Milit. Surg., 99, 528.

Horn, R. C. (1949). Cancer, N.Y., 2, 819

Jacobson, W. (1939). J. Path. Bact., 49,

Kincaid-Smith, $P$, and Brossy, J.-J.'(1956). Thorax, 11, 36.

Lembeck, F. (1953). Nature (Lond.), 172, 910.

Lennard-Jones, J. E., and Snow, P. J. D. (1956). Gastroenterologia (Basel), 85, 169 .

Mattingly, T. W. (1956). Med. Ann. D.C. 25, 304.

Morson, B. C. (1956). Gastroenterologia (Basel), 85, 174.

Nicod, J.-L. (1958). Bull. Ass. franc. Cancer, 45, 214. Schneckloth, R. E., Mclsaac, W. M., and Page, I. H. (1959). J. Amer.
med. Ass., 170, 1143 .

Smith, A. N., Nyhus, L. M., Dalgliesh, C. E., Dutton, R. W., Lennox B., and Macfarlane, P. S. (1957). Scot. med. J., 2, 24.

Stanford, W. R., Davis, J. E., Gunter, J. U., and Hobart, S. G. (1958). Sth. med. J. (Bgham, Ala.), 's1, 449.

Thorson, A. H. (1958). Acta med. scand., Suppl. 334

Biörck, G., Björkman, G., and Waldenström, J. (1954). Amer. Heart J., 47, 795.

Waldenström, J., Pernow, B., and Silwer, H. (1956). Acta med. scand., $\frac{\supset}{\supset}$ 156, 73.

Warner, R. R. P., and Southren, A. L. (1958). Amer. J. Med., 24, 903 . 